\title{
A Combination Design of Bags, Chairs, Chargers, Tables Made with Hazardous Waste Raw Materials in Tackling Environmental Pollution in the 4.0 Revolution Era
}

\author{
Muhamad Fadilah Fatah a,1, ${ }^{*}$, Melyndo Ari Oftariano b,2, Taksulanapurusa Zakly Setiabudi b,3 Eko Sri Haryanto b,4
}

a The Faculty of Visual Arts and Design, Institut Seni Indonesia Surakarta
b The Faculty of Visual Arts and Design, Institut Seni Indonesia Surakarta
${ }^{1}$ alfateh277@gmail.com ${ }^{*} ;{ }^{2}$ 007trus@gmail.com; ${ }^{3}$ ekosriharyanto2015@gmail.com.
${ }^{*}$ Corresponding Author

Received 25 February 2015; accepted 8 May 2015; published 13 May 2015

\section{ABSTRACT}

The design of bags, chairs, chargers and tables is intended for commuter workers who carry out mobility activities every day. Design works that help to support commuter worker activities use a multi-functional system. The multi-function system is indicate by the shape and features attached. This product design method uses several stages including; 1) problem identification; 2) literature study: 3) design sketches, and: 4) design. The design results are turned into chairs, tables for lesehan (sitting on the floor) and bags. In addition, the other things are the storage box to store equipments for commuter workers while doing mobility and a solar cell which functions to capture sunlight which will be converted into electrical energy for energy sources to charge cellphones. Design works can be used in accordance with their respective functions. Design works carry the principle of multifunction, easy use, strong, lightweight and flexible. It is hoped that the design for this multi-functional products can be practical in use in the development of creative industries, and can overcome environmental pollution problems. From a theoretical perspective, it can be a reference for academics and science.

\section{KEYWORDS}

Multifungsion design, inovasition, environment

This is an openaccess article under the CC-BY-SA license

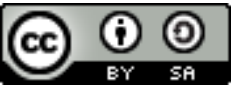

\section{Introduction.}

Developments in various sectors in small, medium, large and megapolitan cities currently become the focus of the government to improve the economy and social equity. One sector of concern is the industrial sector. The industrial sector that grows and develops in big or megapolitan cities is always supported by the surrounding satellite cities. Human resources play a major role in the industrial development. A number of workers in the satellite cities earn income in large cities in the industrial sector. Many of them who come from satellite cities move and settle in industrial cities to get closer to the workplace, but not a few also prefer to commute from their place of residence to work or commonly known as commuters. Commuter workers are the residents at working age who work across the boundaries of the regency / city where they live and return to their place of residence in less than 24 hours. According to data from the Central Statistics Agency in 2019, the results of Jabodetabek Commuter Survey 2019 show that of the 29 million Jabodetabek residents aged 5 years and over, around the 11 percent are the commuters, or around 3.2 million residents. This number is predicted to continue to grow every year. Commuter workers use various modes of transportation to get to their workplaces, such as motorbikes, cars, and public transportation. Commuter worker activities are dense because most of the time spent is working and mobility. Being always productive is a demand in the industrial world. The first problem that exists today is the stress level of commuter workers that is high due to discomfort. A lot of energy, thought and expense are spent. Therefore, there needs to be new solutions and innovations in helping problems for commuter workers. 
On the other hand, the environmental sector should not be neglected. The growing and growing industrial sector causes damaging impacts to the environment. Industrial waste is one of the factors of environmental pollution. One type of industrial waste is B3 or hazardous and toxic waste (Mauluddhina 2019). According to data from the Ministry of Environment and Forestry in 2019 the level of B3 waste reached a total of 88.5 million tons. The waste to manage further reaches a total of 68.4 million tons, while in the temporary storage area reaches 20.1 million tons (Setyanto and Trihadiningrum 2017). The data shows that there is still a problem, the unpreparedness for B3 waste management. Thus, to overcome this problem, it is necessary to use B3 waste which has not been managed to function again as functional objects. One type of waste that can be reused is iron.

Along with the rapid growth of the industry, various problems arise. In the present, which has entered the era of the industrial revolution 4.0 there are new technological advances that integrate three worlds: the digital, physical and biological world (Rizkinaswara 2020).

The extent of this progress has an impact or influence on almost all areas of human life, starting from the economy, industry, government to almost all disciplines. The advancement of technology is a vivid sample of the industrial 4.0 revolution. All turn to digitization to be more effective and efficient. In Indonesia, which is rich in natural resources including sunshine resources because of its location on the equator, such resources can be the capital and strength to face this fourth stage revolution by using them as technological resources.

Based on the aforementioned problems, it can be formulated into how to design objects that can help the effectiveness and efficiency of commuter worker activities by utilizing B3 waste by concerning the suitability on the development of the 4.0 industrial revolution. The purpose of this design is to offer a solution for the wider community and at the same time as a creative innovation.

\section{Method.}

The design of bags, chairs, chargers and tables is intended for commute workers who carry out mobile activities every day. Design works that help to support commute workers' activities use a multifunctional system. The multi-functional system is indicated by the shape and features attached. Design forms can be transformed into chairs, lesehan tables and bags. In addition, there is a storage box to store equipments for commute workers while doing mobility and a solar cell which functions to capture sunlight which will be converted into electrical energy for energy sources to charge cellphones. Design works can be used in accordance with their respective functions. Design work carries the principle of multifunction, easy to use, strong, lightweight and flexible.

To get maximum design results, it is necessary to have design stages to be done. The design methods used are discussed afterwards. There are problems that exist in wider community for which the solutions through innovative design works could be invented. What follows are some of the problems discovered:

1. The discomfort and high stress level of the commute workers in carrying out work activities that require a lot of energy, thought and money.

2. The unpreparedness of industrial companies in managing the B3 waste they produce.

3. The Industrial 4.0 Revolution which makes all kinds of activities digitalized and technological basis.

At this stage, the literature data related to the problems were explored further. Additionally, some supporting data for design process including data on design aspects and similar previously created works are used for novelty comparison.

A rough sketch functions as an early depiction of a design work.(Olofsson and Sjolen 2006). At this stage, several design alternatives will be created as considerations. Then, one of them will be selected to be processed to the next stage.

The selected design will be developed by applying ergonomic standards. The goal is that a design work created becomes comfortable, effective, and efficient to assist commute worker activities. Ergonomics aspects are applied concerning size and shape so that they are comfortable to use following human body (Kusyanto 2013).

The construction system of connection and lock is a major concern to create a design work that is strong and safe to use. In addition, the construction system is also important as a form changer in design because the result of the design works will apply the principle of multi-functions.

The character of the forming material is both the main and supporting material. The character of the material is a consideration to create a design work that is lightweight and safe to use under certain 
conditions. Another consideration that needs to be considered is that the preferred material is B3 waste, that is iron, and there is also an electrical system for the charger.

The design results after going through developments from various design aspects then meet an evaluation. The evaluation is carried out to minimize shortcomings and errors, by reconciling the design results with literature data. If there are deficiencies or errors, it returns to the initial design process which is the redesigning process with a rough sketch.

After the design is evaluated, the process that follows is the finalization. At this stage, there will be the creation of working drawings, modeling, and animation based on the design works. The aim is to improve the information and description of the design so that the original picture of the design work is highlighted.

\section{Results and Discussion}

The mobility pattern of the Indonesian population has changed from time to time, from permanent mobility to non-permanent mobility. Non-permanent mobility is divided into two categories based on routine aspects, namely circular (circulatory mobility) and commuting (shuttle mobility). Circulatory mobility occurs when residents who have moved since the beginning have intended to return to their hometowns. Shuttle or commuter mobility occurs due to movements carried out within one day by crossing regional boundaries and returning to their hometown areas.

The activities of commuters in general are in the context of: work, school, and/or other activities. Commute workers are the residents at working age who work across the boundaries of the regency/city where they live and return to their place of residence in less than 24 hours. According to Matra IB, those who work across district/city boundaries are generally due to the absence of work opportunity in the area where they live, and/or because there are better job options compared to those in their area. With such high level of activities and large expenses on time, energy, thoughts, and costs, these commute workers have a high level of stress tendencies.

The results of the 2019 Jabodetabek Commuter Survey show that of the 29 million Jabodetabek residents aged 5 years and over, around 11 percent are commuters. Of the 3.2 million Jabodetabek commuters, 67 percent are men. 71 percent of commuters in Jabodetabek are in the productive age group (15 - 44 years), 19 percent are in the 45-54 age group, 4 percent are 5-14 years old, and 6 percent are 55 years and over. Jabodetabek commuters are mostly in the 15-24 year age group (27 percent).

Most commuters (80 percent) use one time mode of transportation to go to their place where their activities are going. Only 18 percent of the commuters use more than one mode of transportation, and the rest is walking. The main modes of transportation that were mostly used to commute to the place of activities were motorbikes (63.3 percent) and public transportation (26.9 percent). 15.1 percent of Jabodetabek commuters had problems of fever, 27.2 percent had coughs/colds, 19.2 percent had headaches, 7.3 percent had sore throats, 1.7 percent had eye pain, 1.7 percent had shortness of breath, 31.6 percent catch a cold, and 37.2 percent experienced fatigue.

According to data from the Ministry of Environment and Forestry in 2019 the level of B3 waste reached a total of 88.5 million tons. The waste that is furtherly managed is a total of 68.4 million tons, while that is in the Temporary Storage reaches 20.1 million tons. The data shows that there is a problem, namely the unpreparedness for $\mathrm{B} 3$ waste management. To overcome this problem, it is necessary to use $\mathrm{B} 3$ waste that has not been managed to make it to be used again becoming functional objects. One type of waste that can be reused is iron.

A multi-function table is a table that can be used for several functions for various purposes (Suhartini 2020). Furniture or multi-functional tables have several advantages including the efficiency in the use of space (Poetra 2016). The multi-function table for studios has a surface of $600 \mathrm{~mm}$ in depth and a length of up to $1500 \mathrm{~mm}$ with a height of $750 \mathrm{~mm}$ which conforms to human ergonomic standards. This table has a function as a mockup table which the base is made of cutting mats and for maintenance the cutting mats can be either replaced or updated. This is also objected to anticipate the cutting activity using sharp tools such as razors, scissors, or hard glue can be done without damaging the table base. The small folding table can also be used as a portable table and can be used for light loads such as a laptop or food and drinks. The computer desk is the main part as a work facility for placing computers on this multifunctional table (Andansari and Aglisyifa 2020). The monitor placement base is permanently functioned and does not move so that the cable management and the monitor's visibility to the user remain stable. This multifunctional table is also equipped with storage container facilities to 
accommodate user's objects and tools. With all the considerations of finishing and colors of the design work, by analyzing the surrounding environment of the studio type apartment space and the use of contemporary, futuristic design styles according to the concept of transformers and a combination of colors that match the modern minimalist style of the space so that the furniture seems to blend with the room.

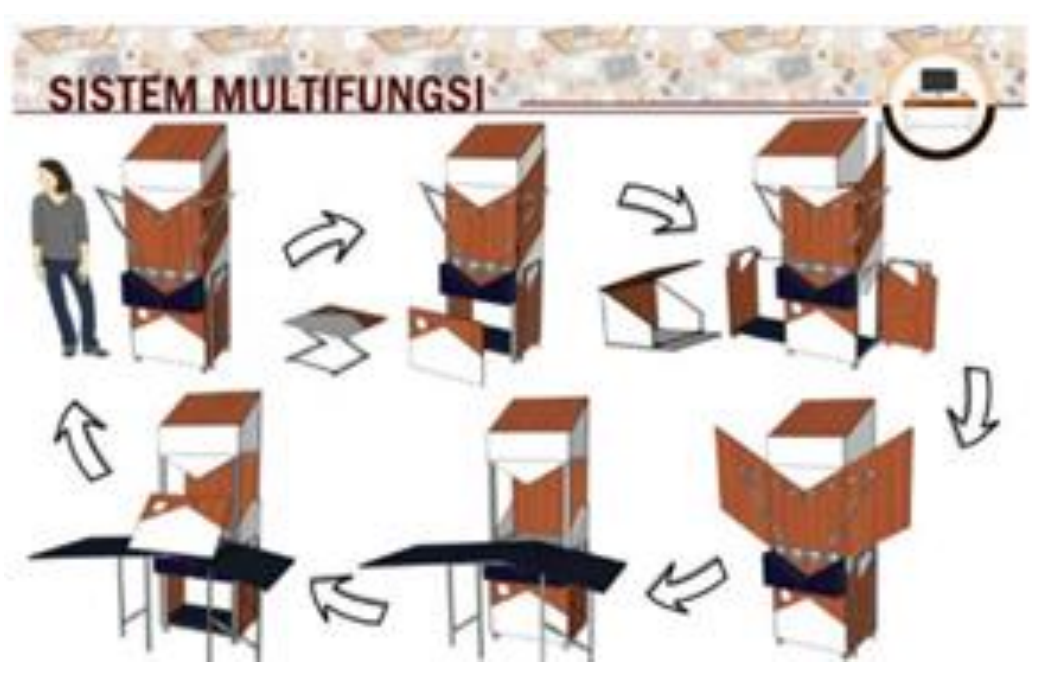

Fig. 1. Multi-functions designs (source $\mathrm{xxxxx}$ ).

Solar cells are active elements that convert light energy into electrical energy, with a principle called the photovoltaic effect. Solar cells are made of semiconductor wafers with positive and negative poles, the same as a diode, only the surface is made wide so that it can capture as much sunlight as possible. When light falls on the surface of the solar cell, there will be a difference in voltage.

Solar cell is a semi-conductor device that can generate electricity when given a certain amount of light energy. The process of generating electrical energy occurs when the bonding of electrons in the atoms arranged in a semiconductor crystal is broken when a certain amount of energy is given (Prayitno and Roza 2018). One of the semiconductor materials commonly used as solar cells is silicon crystals (Ady Iswanto: 2008)

Design work carries a multifunctional concept to support commute workers' activities, such like the combination of table, chair and bag functions. In addition, this work involves one of the B3 wastes that is iron as the main material in an effort to tackle environmental pollution due to iron waste. Adding a cellphone charger feature by utilizing sunlight through solar cells is a form of adaptation during the 4.0 revolution.

Based on the results of the 2019 Jabodetabek commuter survey, 71 percent of commuters in Jabodetabek are in the productive age group, namely those aged 15 - 44 years (Indah, Susantono, and Riyanto 2015). Thus, the size of the design made must follow the anthropometry or body size of the 1544 year age group (Joseph De Chiara, Panero, and Zelnik 1992). The purpose is to provide comfort and effectiveness.

Based on the dimension data, the size of chair seat for age of 15-44 years old is $43 \mathrm{~cm}-55 \mathrm{~cm}$. Meanwhile, the seat height for 15-44 years old is $37.8 \mathrm{~cm}-47.8 \mathrm{~cm}$. The design work to be created is a chair with a circular sitting base. Therefore, the dimension of the design work is the sitting base measuring $45 \mathrm{~cm}$ in diameter and $40 \mathrm{~cm}$ in height. When changing its function to a flat table, the height will be lowering to $20 \mathrm{~cm}$.

The main material used is a B3 waste which is iron. The iron used is hollow iron pipes and solid iron pipes. A hollow iron pipe measuring $5 \mathrm{~cm}$ in diameter functions as a sitting base shaper. The making process is, first, it is heated to make it easy to shape. Then it is curved so that it forms a circle measuring $45 \mathrm{~cm}$ in diameter as the sitting base of the seat. The two ends of the iron pipe are then connected by welding the iron. After that, the finishing process applies powder coating. Meanwhile, the solid iron pipes are used for the legs with a diameter of $2 \mathrm{~cm}$. Solid iron pipes are used on the feet to support the 
load on the sitting base. The finishing process is the coating of workpieces to improve the beauty and quality of the design products (Sumarno et al. 2019).

Another supporting material is a wooden board as the sitting base with a diameter of $40 \mathrm{~cm}$ and a thickness of $1 \mathrm{~cm}$. The base is made of wood to prevent electricity flow from the charger. Wooden boards function as an electrical insulator, as a substance for resisting electricity, for the user's safety. The finishing process uses woodstain to highlight the character of the wooden planks and maintain durability.

Another material is the blue canvas fabric. Canvas fabric is used as a cover and covering for storage. Besides, canvas fabric is also used as a place to put solar cells and power banks. Canvas fabric is affixed around the hollow iron pipe to cover the inside part. Canvas fabric is also chosen because of its characteristic as an electrical insulator or resistant to electricity. This is a major concern because the canvas is in direct contact with the electricity system including the solar cells and power bank.

The next material is the solar cells power bank. The energy of this powerbank is sourced from sunlight. It has dimension of $12 \mathrm{~cm} \mathrm{X} 7.5 \mathrm{~cm} \mathrm{X} 2.5 \mathrm{~cm}$ and weighs 350gram (which is very light and easy to carry). It has 3 batteries, each of them having a capacity of $10,000 \mathrm{mAh}$. Charging duration is 812 hours depending on the weather. In this design work, the position of the power bank of the solar cells is on the outside, more precisely is attached to the canvas to make it easier to receive sunlight.

The interior equipment chair is a facility used for sitting (Sumarno 2015), (Gardner et al. 2019). When it is used as a chair, the user needs to position the legs by turning them down so that they can support the base of the seat. This chair is predicted to be able to accommodate the weight of the human body of $80 \mathrm{~kg}$ at maximum. With the support of four legs made of solid iron pipes, the chair will stand firm.

When the user wants to change the chair into a lesehan table (table used when people sitting down on the floor with no chair), they can lower the height of the legs by adjusting the half height of the legs in so that the height becomes $20 \mathrm{~cm}$. This lesehan table can be used to do activities either for writing or working with a laptop because the diameter of the base is quite wide, measuring $45 \mathrm{~cm}$. Thus, it can be used for laptops and mouse, making it easier to do tasks.

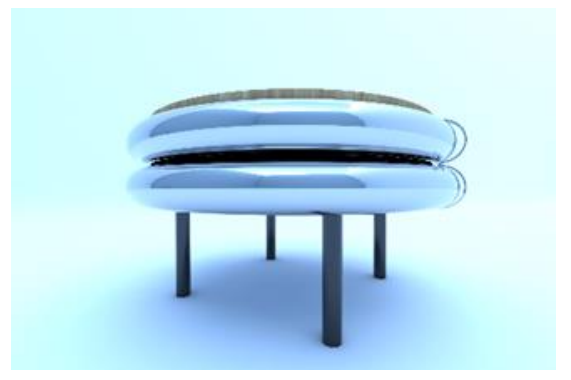

Fig. 2. The Table Design

To change the function into a bag, the legs can be inserted into the inner area. Then the table base is rotated 360 degrees. After that, the solar cells power bank will be visible. This bag is included in a backpack. When it functions as a bag, the solar cells can work for charging by absorbing sunlight energy during the user's mobility. The bag storage space is large enough to store laptops and other working tools. The load that can be accommodated is a $10 \mathrm{~kg}$ at maximum for user convenience. Items that can be put into the bag are the belongings of the commute workers such as laptops, wallets, cellphones and office stationery. Items that are not recommended to be included in are drinking bottles or items containing water because there is an electric current system which can cause accidents.

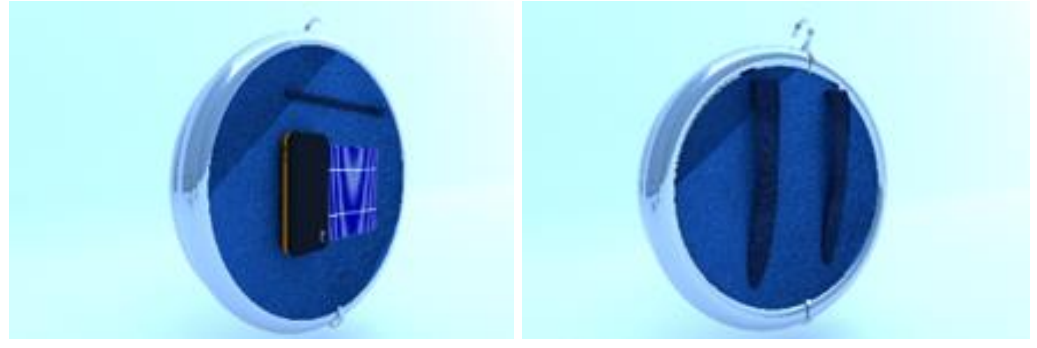

Fig. 3. The Bag Design. 


\section{Conclusion}

The industrial sector that grows and develops in big or megapolitan cities is always supported by the surrounding satellite cities. Human resources play a major role in industrial development. A number of workers in satellite cities earn income in big cities in the industrial sector. Many of them move and settle in industrial cities to be closer to the workplace, but not a few also prefer to commute from their place of residence to work or commonly known as commuters.

The growing industrial sector causes damaging impacts to the environment. Industrial waste is one of the factors of environmental pollution. One type of industrial waste is the hazardous and toxic waste (B3). To overcome this problem, it is necessary to make use of B3 waste that has not been managed to be used again as functional objects. One of the waste types that can be reused is iron.

Design works carry a multifunctional concept to support commute workers' activities by creating a combination of table, chair, and bag functions. Using B3 waste, iron, as the main material is an effort to tackle environmental pollution due to iron waste. Adding a cellphone charger feature by utilizing sunlight through solar cells is a form of adaptation in the 4.0 revolution era. 


\section{References}

Andansari, Dita, and Nadya Aglisyifa. 2020. "DESAIN MEJA TAMU." Jurnal Kreatif : Desain Produk Industri Dan Arsitektur 6 (1). https://doi.org/10.46964/jkdpia.v6i1.35.

Gardner, Benjamin, Stuart Flint, Amanda L. Rebar, Stephen Dewitt, Sahana K. Quail, Helen Whall, and Lee Smith. 2019. "Is Sitting Invisible? Exploring How People Mentally Represent Sitting." International Journal of Behavioral Nutrition and Physical Activity 16 (1). https://doi.org/10.1186/s12966-019-0851-0.

Indah, Febriamitha, Bambang Susantono, and Bambang Riyanto. 2015. "Analisis Tingkat Pelayanan Transportasi Berkesinambungan (Seamless Service) (Studi Kasus: Perjalanan Komuter Jabodetabek Melalui Stasiun Kereta Api Bekasi)." JURNAL PEMBANGUNAN WILAYAH \& KOTA 11 (3). https://doi.org/10.14710/pwk.v11i3.10856.

Joseph De Chiara, Julius Panero, and Martin Zelnik. 1992. Time Saver Standards for Interior Design and Space Planning. New York: Mc Graw Hill.

Kusyanto. 2013. "Herry Koesyanto." KESMAS - Jurnal Kesehatan Masyarakat 9 (1).

Mauluddhina, Ika. 2019. "Eksekusi Putusan Tindak Pidana Lingkungan Hidup Terkait Limbah Bahan Berbahaya Beracun (B3)." Media luris 2 (1). https://doi.org/10.20473/mi.v2i1.11358.

Olofsson, Erik, and Klara Sjolen. 2006. Design Sketching.Pdf. 2nd ed. Klippan, Sweden: KEEOS Design Book.

Poetra, Burhan Leonardi. 2016. "Perancangan Perabot Multifungsi Untuk Ruang Huni Terbatas." Intra 4 (2).

Prayitno, Gunarwan, and Emilia Roza. 2018. "Analisa Matematik Karakteristik Detector Semikonduktor Silicon Tipe P Sebagai Bahan Detector Partikel Radiasi Bermuatan." Prosiding Seminar Nasional Teknoka 3. https://doi.org/10.22236/teknoka.v3i0.2822.

Rizkinaswara, Leski. 2020. "Revolusi Industri 4.0." Infrastruktur TIK, no. 28 January.

Setyanto, Ignatius Chandra, and Yulinah Trihadiningrum. 2017. "Kajian Pengelolaan Limbah Elektronik Di Unit Pendidikan ITS." Jurnal Teknik ITS 6 (2). https://doi.org/10.12962/j23373539.v6i2.25320.

Suhartini. 2020. "Pengembangan Produk Meja Belajar Multifungsi Dengan Menggunakan Metode Quality Function Deployment Dan Antropometri." Jurnal Tecnoscienza 4 (2).

Sumarno. 2015. "Cakruk as Local Wisdom and Reflection of Ancient Javanese Architecture in Indonesian." Art and Design Studies 34 (0): 27-35. http://iiste.org/Journals/index.php/ADS/article/view/24594.

Sumarno, Dharsono, Guntur, Agung Purnomo, and Bagus Setyawan. 2019. "Rattan Batik: Local Wisdom-Based Rattan Furnitures Finishing Industry." In SEWORD FRESSH 2019. EAI. https://doi.org/10.4108/eai.27-4-2019.2286919. 